\title{
VERBA BERPELENGKAP DALAM BAHASA INDONESIA SUATU KAJIAN STRUKTUR DAN SEMANTIK
}

\author{
Eni Karlieni \\ Fakultas Sastra Unpad Bandung
}

\begin{abstract}
This research study attempts to describe morphological forms of verbs with complements in Indonesian and their syntactic and semantic characteristics.

The method employed in this study was the descriptive one, which was synchronically applied. The data sources were Indonesian textbooks for elementary schools, junior high schools, and senior high schools, besides newspapers such as Kompas, Republika and Pikiran Rakyat.

Morphologically, verbs with complements can be free verb bases, derived verbs, and reduplicated verbs. On the basis of their syntactic characteristics, the verbs can be those with noun complements (noun phrases), verbals (verbal phrases), adjectives (adjectival phrases), adverbials (adverbial phrases), and numbers (numeral phrases). On the basis of their semantic characteristics, the verbs can be classified into punctual verbs, dynamic verbs, and static verbs.
\end{abstract}

Keywords: argument, complement, constituent

\section{A. Pendahuluan}

\section{Latar Belakang Masalah}

Verba (V) mempunyai kedudukan yang utama karena peranannya dalam kalimat dan kekayaan bentuk-bentuknya (Coolsma, 1985:80). Kedudukan yang sentral tersebut akan menentukan hadirnya ko-konstituen (argument), baik konstituen praverba maupun konstituen postverba. Jumlah ko-konstituen yang harus hadir dalam sebuah klausa sangat bergantung pada struktur semantik verba. Struktur semantik verba dapat pula menentukan jenis ko-konstituen dan relasi yang terjalin antara verba dengan kokonstituen tersebut.

Menurut Kridalaksana (1990:51-58) dan Moeliono (1997-139) berdasarkan banyak argument, verba dibedakan atas verba monotransitif \{verba yang diikuti satu objek (dua argument)\}, verba bitransitif \{verba yang diikuti objek dan pelengkap (tiga argument)\}, dan verba ditransitif (verba yang objeknya tidak muncul). Verba intransitif dibedakan atas verba semitransitif (verba berpelengkap wajib), verba taktransitif (verba tak berpelengkap), dan verba semitransitif-taktransitif (verba manasuka).

Perhatikan contoh-contoh berikut!

(1) Mahasiswa membuat karangan ilmiah

(2) Istana itu berlantaikan marmer

(3) Keluargaku tinggal di Bandung

(4) Wajah-wajah muda tertunduk lesu

Verba-verba di atas memperlihatkan bentuk, perilaku sintaktis, dan perilaku semantik yang berbeda-beda. Verba membuat diikuti konstituen posverba berupa objek berkategori frasa nominal, verba berlantaikan diikuti pelengkap yang bersifat wajib berkategori nomina, verba tinggal diikuti keterangan yang bersifat wajib berkategori frasa preposisional, dan verba tertunduk diikuti 
keterangan (mirip pelengkap) bersifat manasuka berkategori adjektiva. Jalinan antara verba dengan konstituen praverba (dalam hal ini subjek) termasuk verba antiaktif dan verba antipasif.

Jenis pengisi predikat verba berpelengkap sangat bervariasi. Secara morfologis, verba tersebut dapat diisi oleh verba dasar dan turunan. Kehadiran konstituen posverba dapat diisi oleh bermacam-macam kategori. Kehadiran konstituen posverba ada yang bersifat takwajib, wajib, dan manasuka. Beranjak dari hal itu, penelitian terhadap verba berpelengkap menarik untuk dikaji.

\section{Tujuan Penelitian}

Tujuan penelitian ini adalah sebagai berikut.

a. mengkaji dan mendeskripsikan bentuk morfologis verba berpelengkap dalam bahasa Indonesia;

b. mengkaji dan mendeskripsikan perilaku sintaktis verba berpelengkap dalam bahasa Indonesia;

c. mengkaji dan mendeskripsikan perilaku semantis verba berpelengkap dalam bahasa Indonesia.

\section{Landasan Teori}

Dalam penelitian ini, pelengkap dipahami sebagai bagian dari predikat verba yang melengkapi verba tersebut. Verba di sini bukan verba transitif, melainkan verba semitransitif (bagian dari verba intransitif).

Menurut Sugono dan Titik (1990:34) verba intransitif adalah verba yang tidak memiliki nomina di belakangnya yang dalam kalimat pasif nomina itu dapat berfungsi sebagai subjek.

Menurut Kridalaksana (1990:49) berdasarkan bentuknya, verba dibedakan atas (1) verba yang berupa morfem bebas dan (2) verba turunan, yaitu verba yang telah mengalami afiksasi, reduplikasi, gabungan proses, atau berupa paduan leksem. Namun, penelitian ini hanya membahas verba yang berupa morfem bebas dari verba turunan yang mengalami afiksasi dan reduplikasi.

Dari segi perilaku sintaktis, Moeliono (1997) berpendapat bahwa verba intransitif terdiri atas (a) verba semitransitif yaitu verba yang berpelengkap wajib, (b) verba taktransitif yaitu verba yang tidak berpelengkap manasuka.

Tadjuddin (1993:25) melihat verba dari segi semantis. Berdasarkan makna keaspekan verba bahasa Indonesia dikelompokkan menjadi empat jenis, yaitu (1) verba pungtual, (2) verba aktivitas, (3) verba statis, dan (4) verba statif.

\section{B. Metode Penelitian}

Metode yang digunakan dalam penelitian ini adalah metode deskriptif dengan jangkauan waktu bersifat sinkronis. Penggunaan metode deskriptifsinkronis dipertimbangkan atas pemusatan perhatian pada ciri-ciri dan sifat-sifat data bahasa secara alami, sehingga menghasilkan pemerian data bahasa yang aktual (Djajasudarma, 1993:7). Data yang dikaji bersumber pada bahasa Indonesia tulis. Sumber data diambil dari buku-buku pelajaran Bahasa Indonesia SD, SLTP, SMA. Di samping itu, digunakan pula surat kabar Kompas, Pikiran Rakyat, dan Republika.

\section{Hasil Penelitian \\ 1. Bentuk Verba Berpelengkap}

Verba berpelengkap berdasarkan bentuk morfologisnya dapat diklasifikasikan menjadi verba bentuk dasar dan verba bentuk turunan. Verba bentuk turunan yang dibentuk melalui proses afiksasi disebut verba berafiks, sedangkan verba bentuk turunan yang dibentuk melalui proses reduplikasi disebut verba bereduplikasi. 


\section{a. Verba Bentuk Dasar}

Berikut ini contoh-contoh klausa berpelengkap yang verbanya berupa bentuk dasar.

(5) Pasien minum obat

(6) Mereka makan sagu

Verba minum (5) dan makan (6) pada klausa di atas tergolong verba dasar. Verba-verba tersebut merupakan bentuk yang mempunyai makna mandiri walaupun tanpa imbuhan. Verba-verba tersebut disebut verba aus (verba zero).

\section{b. Verba Bentuk Turunan}

Verba turunan artinya verba yang telah mengalami proses morfemis, baik melalui afiksasi maupun reduplikasi. Dalam hal ini, verba turunan yang dibentuk melalui proses afiksasi disebut verba berafiks, sedangkan verba turunan yang dibentuk melalui proses reduplikasi disebut verba bereduplikasi.

\section{c. Verba Berafiks}

Afiks bahasa Indonesia meliputi prefiks, infiks, sufiks, gabungan afiks, dan konfiks. Verba berpelengkap berafiks sebagian besar dibentuk dengan prefiks, konfiks, dan gabungan afiks (prefiks dan sufiks). Pembentukan verba berpelengkap khususnya dan konstruksi verbaverba lain pada umumnya dengan infiks tidak produktif. Sementara itu, sufiks sebagai pembentuk verba berpelengkap biasanya disertai pula dengan prefiks, atau merupakan gabungan afiks.

Verba berpelengkap berafiks pada umumnya melibatkan prefiks me(N)-, be(R)-, dan te(R)-, gabungan afiks me(N)kan, me(N)-I, ber-an, dan ke-an.

\section{1) Verba Berpelengkap Berprefiks $\mathrm{Me}(\mathrm{N})$ -}

Berikut ini contoh-contoh kalimat verba berpelengkap berprefiks me(N)-.

(7) Kurniawan banyak merokok kretek
(8) Mereka akan menujuh hari kematian orang tuanya

(9) Mereka menjadi salah satu pemain top ganda

(10) Ibnu Sutowa sudah meninggal dunia

Verba merokok (7), menujuh (8), menjadi (9), dan meninggal (10), pada klausaklausa di atas tergolong verba berpelengkap. Verba-verba tersebut masing-masing dibentuk dari prefiks me(N)- dengan bentuk dasar. Verba merokok dibentuk oleh bentuk dasar rokok berkategori nomina, verba menujuh dibentuk oleh bentuk dasar tujuh berkategori numeralia, verba menjadi dibentuk oleh bentuk dasar jadi dan verba meninggal dibentuk dari bentuk dasar tinggal berkategori verba. Dengan demikian, bentuk verba berpelengkap berafiks me $(N)$ - dapat bergabung dengan bentuk dasar berkategori nomina, verba, dan numeralia.

\section{2) Bentuk Verba Berpelengkap Ber- prefiks be(R)}

Berikut ini adalah contoh-contoh klausa dengan verba berpelengkap yang berprefiks be(R)-.

(11) Mereka berdagang makanan

(12) Kabinet ini berumur kurang dari setahun

(13) Kuda dan sapi berkaki empat

Verba berdagang (11), berumur (12), dan berkaki (13) dalam klausa-klausa di atas tergolong verba berpelengkap. Verba-verba tersebut masing-masing dibentuk dari prefiks ber- dengan bentuk dasar dagang yang berkategori verba, umur dan kaki yang berkategori nomina.

\section{3) Bentuk Verba Berpelengkap Ber- prefiks te(R)-}

Berikut ini contoh-contoh klausa verba berpelengkap yang berprefiks te(R)-.

(14) Bintang film itu termasuk gadis yang baik 
(15)... pronogisnya pun tidak terlampau baik

Verba termasuk (14) dan terlampau (15) yang terdapat di dalam klausa-klausa di atas tergolong verba berpelengkap. Verba-verba tersebut masing-masing dibentuk dari prefiks ter-dengan bentuk dasar masuk dan lampau yang berkategori verba.

\section{4) Bentuk Verba Berpelengkap Be- rafiks me(N)-i}

Berikut ini contoh-contoh klausa dengan verba berpelengkap yang berafiks me(N)-.

(16) Kamu menyamai kepandaiannya

(17) Lina menyerupai ibunya

Verba menyamai (16) dan menyerupai (17) dalam klausa-klausa di atas tergolong verba berpelengkap. Vetha menyamai dibentuk dari afiks me-i dengan bentuk dasar sama yang berkategori adjektiva dan verba menyerupai dibentuk dari afiks me-i dengan bentuk dasar rupa yang berkategori nomina.

\section{5) Verba Berpelengkap Berafiks me $(N)-k a n$ \\ Berikut ini contoh-contoh klau-} sa verba berpelengkap yang berafiks me(N)-kan.

(18) Pematokan itu merupakan puncak ketidakpuasan

(19) Kemenangannya akan menggembirakan semua pihak

Verba merupakan (18) dan menggembirakan (19) dalam klausaklausa di atas tergolong verba berpelengkap. Verbaverba tersebut masing-masing dibentuk dari afiks me(N)-kan dengan bentuk dasar rupa yang berkategori nomina dan gembira berkategori adjektiva.

\section{6) Verba Berpelengkap Berafiks be(R)-kan}

Berikut ini contoh-contoh klausa verba berpelengkap berafiks ber-kan.

(20) Buku ini berdasarkan kurikulum

(21) Pemuda itu bermandikan keringat

Verba berdasarkan (20) dan bermandikan (21) tergolong verba berpelengkap. Verba-verba tersebut dibentuk dari afiks ber-kan dengan bentuk dasar dasar yang berkategori nomina dan bentuk dasar mandi yang berkategori verba. Proses pembentukan kedua verba di atas berbeda. Pada kata berdasarkan, afiks bermenempel lebih dahulu pada bentuk dasar dasar menjadi berdasar kemudian sufiks - kan menempel pada bentukan itu menjadi berdasarkan, sedangkan pada verba bermandikan, sufiks - kan menempel lebih dulu pada bentuk dasar menjadi mandikan, kemudian prefiks berbergabung pada bentukan itu menjadi bermandikan. Proses pembentukan kata kata tersebut secara ringkas dapat dijelaskan sebagai berikut.

dasar $\rightarrow$ berdasar $\rightarrow$ berdasarkan mandi $\rightarrow$ mandikan $\rightarrow$ bermandikan

\section{7) Bentuk Verba Berpelengkap Be- rafiks be(R)-an}

Berikut ini contoh-contoh klausa verba berpelengkap yang berafiks $b e(R)$.

(22) Mereka berlangganan harian Kompas

(23) Guru-guru berpakaian putihputih

Verba berlangganan (22) dan berpakaian (23) tergolong verba berpelengkap. Ber-an pada kata-kata tersebut tidak menempel secara serempak, tetapi secara bertahap. Sufiks -an menempel lebih dahulu pada bentuk dasar langgan yang berkategori verba menjadi langganan dan pakai yang berkategori verba menjadi pakaian, kemudian prefiks ber- menem- 
pel pada bentukan itu menjadi berlangganan dan berpakaian. Proses pembentukan kata-kata tersebut dapat dijelaskan sebagai berikut.

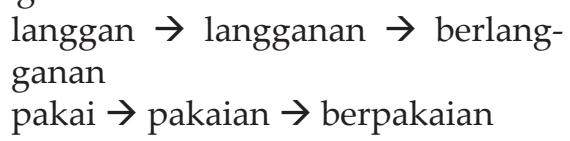

\section{8) Bentuk Verba Berpelengkap Berkonfiks ke-an}

Berikut ini contoh-contoh klausa verba berpelengkan yang berkonfiks $k e-$ an.

(23)... mereka keracunan ikan kembung

(24) Jiwanya telah beberapa kali kerasukan roh jahat

(25) Penduduk desa kekurangan bahan makanan

Verba keracunan (24), kerasukan (25), dan kekurangan (26) tergolong verba berpelengkap. Verba-verba tersebut dibentuk oleh konfiks ke-an dengan bentuk dasar racun berkategori nomina, rasuk berkategori verba, dan kurang berkategori adverbial. Ciri bahwa ke-an itu konfiks terbukti dengan tidak berterimanya bentuk-bentuk seperti *keracun, *racunan, *kerasuk, "rasukan, *kekurang, *kurangan.

\section{d. Verba Bereduplikasi}

Berikut ini contoh-contoh klausa verba berpelengkap yang verbanya bereduplikasi.

(27) Anak manja itu berpura-pura sakit

(28) Penonton bersorak-sorai kegirangan

(29) Ia tak sanggup berkata-kata lagi

(30) Gadis itu tersipu-sipu malu

Verba-verba di atas dibentuk secara reduplikatif. Verba berpura-pura (27) berpola prefiks+(dasar+dasar) yang diturunkan dari pura-pura (reduplikasi fonologis) kemudian ditambah prefiks be(R)-.Verba bersorak-sorai (28), berkata- kata (29), dan tersipu-sipu (30) berpola (prefiks+dasar)+dasar. Verba bersorak-sorai diturunkan dari bersorak kemudian mengalami perubahan bunyi, verba berkata-kata diturunkan dari berkata yang kemudian diikuti oleh bentuk dasar kata, verba tersipu yang kemudian diikuti oleh bentuk dasar terikat sipu.

Dari uraian di atas dapat disimpulkan bahwa secara morfologis bentuk verba berpelengkap dapat diisi oleh verba dasar bebas, verba turunan, dan verba bereduplikasi. Verba turunan berafiks dapat dibentuk oleh afiks me-(N)dengan bentuk dasar nomina, verba, dan numeralia, $b e(R)$ - dengan bentuk dasar nomina dan verba, te(R)- dengan bentuk dasar verba, me(N)-i dengan bentuk dasar nomina dan adjektiva, me(N)-kan dengan bentuk dasar nomina dan adjektiva, be(R)-kan dengan bentuk dasar nomina dan verba, be(R)-kan dengan bentuk dasar verba, dan konfiks ke-an dengan bentuk dasar nomina, verba, adjektiva, adverbia, dan numeralia. Verba bereduplikasi dapat dibentuk melalui afiksasi dengan pola prefiks+(dasar+dasar) dan melalui perubahan bunyi dengan pola (prefiks+dasar)+dasar.

\section{Perilaku Sintaktis Verba Berpe- lengkap}

Berdasarkan perilaku sintaktis, verba berpelengkap dapat dibedakan atas verba berpelengkap wajib dan verba berpelengkap manasuka.

\section{a. Verba Berpelengkap Wajib}

Verba berpelengkap wajib tidak memiliki nomina di belakangnya yang dapat berfungsi sebagai subjek dalam kalimat pasif. Verba berpelengkap wajib artinya verba tersebut diikuti konstituen pelengkap (bukan objek).

Moeliono(1997:138) menyebut verba berpelengkap dengan dua argumen ini dengan istilah verba semitransitif. Verba 
semitransitif ialah verba intransitif yang memerlukan konstituen pelengkap di belakang predikat verbanya.

\section{1) Verba Berpelengkap Nominal (Fra- sa Nominal)}

Berikut ini contoh-contoh klausa berpelengkap nomina (frasa nominal).

(31)... teman karib berkirim surat kepada saya

(32) Lina menyerupai ibunya

(33) Pancasila merupakan dasar negara Republik Indonesia

(34) Mereka menjadi salah satu pemain top ganda

(35) Pemuda itu bermandikan keringat

Konstituen posverba pada klausa (31) sampai dengan (35) berfungsi sebagai pelengkap. Pelengkap klausa-klausa tersebut adalah kata surat, ibunya, dan keringat yang berkategori nomina dan frasa dasar negara Republik Indonesia dan salah satu pemain top ganda yang berkategori nomina.

\section{2) Verba Berpelengkap Verba}

Berikut ini contoh-contoh klausa berpelengkap verba.

(36) Laki-laki itu kedapatan mencuri

(37) Anak itu ketahuan merokok

Verba kedapatan (36) dan ketahuan (37) dalam klausa di atas diikuti konstituen posverba mencuri dan merokok yang berkategori verb.

\section{3) Verba Berpelengkap Adjektiva}

Berikut ini contoh-contoh klausa berpelengkap adjektiva.

(38) Hatinya bertambah bulat

(39) Ia kelihatan baik

(40) Anak manja itu berpura-pura sakit

Verba bertambah (38), kelihatan (39), dan berpura-pura (40) diikuti konstituen posverba berupa pelengkap bulat, baik, dan sakit yang berkategori adjektiva.

\section{4) Verba Berpelengkap Numeralia (Frasa Numeral)}

Berikut ini contoh-contoh klausa berpelengkap numeralia (frasa numeral).

(41)Kekayaannya berjumlah milyaran rupiah

(42) Ruangan itu beralaskan sehelai tikar

Verba berjumlah (41) dan beralaskan (42) dalam klausa di atas diikuti konstituen posverba berupa pelengkap milyaran rupiah dan sehelai tikar yang berkategori frasa numeral.

Verba-verba dalam klausa (31) sampai dengan (42) diikuti oleh konstituen posverba berupa pelengkap. Pelengkap pada klausa-klausa tersebut berupa kata atau frasa yang berkategori nomina, verba, adjektiva, atau numeralia. Dikatakan sebagai pelengkap karena konstituen posverba tersebut tidak mungkin dapat diubah menjadi subjek bila klausa dipasifkan. Posisi pelengkap pun bersifat statis, tidak mungkin dapat dipermutasikan dan tidak dapat disubtitusi dengan -nya. Kehadiran konstituen posverba tersebut bersifat wajib hadir. Bila pelengkap dihilangkan klausa menjadi tidak berterima.

Berdasarkan data yang ditemukan, klausa berpelengkap wajib itu berupa klausa dengan predikat verba kopulatif, seperti terdapat dalam (33) dan (34). Menurut Kridalaksana (1993:121), kopula (copula, copulative verb, equation verb, catenative verb, connector) adalah verba yang menghubungkan subjek dengan komplemen, misalnya ing be, seem, become, dan lain-lain dan verba kopulatif ialah verba yang berpotensi untuk dihilangkan tanpa mengubah konstruksi yang bersangkutan, misalnya menjadi, merupakan (1993:227).

Dalam penelitian ini, kata kopulatif hanya bersifat verbal, yaitu menjadi dan merupakan (Verhaar, 1997:95). Verba ko- 
pulatif tergolong verba semitransitif karena mempunyai dua argument, yaitu subjek dan pelengkap yang bersifat wajib.

\section{b. Verba Berpelengkap Manasuka}

Pelengkap yang bersifat manasuka kehadirannya bersifat opsional, boleh ada boleh juga tidak ada. Meskipun pelengkap dihilangkan, klausa tetap berterima. Menurut Moeliono (1997:261) verba semacam ini tergolong verba semitransitif taktransitif, yaitu verba intransitif yang mempunyai pelengkap, tetapi pelengkap itu tidak bersifat wajib.

\section{1) Verba Berpelengkap Nomina (Fra- sa Nominal)}

Berikut ini contoh-contoh klausa berpelengkap nomina (frasa nominal).

(43) Ayah berdagang barang-barang antik

(44) Mereka berlangganan harian Kompas

(45) Jiwanya telah berkali-kali kerasukan roh jahat

(46) Penonton bersorak-sorai kegirangan

Verba berdagang (43), berlangganan (44), kerasukan (45), bersorak-sorai (46) diikuti konstituen posverba berupa pelengkap. Pelengkap dalam klausa-klausa di atas adalah barang-barang antik, harian Kompas, roh jahat berkategori frasa nominal, dan kegirangan berkategori nomina.

\section{2) Verba Berpelengkap Verba (Frasa Verbal)}

Berikut ini contoh-contoh klausa berpelengkap verba (frasa verbal)

(47) Mereka berjalan menyusuri lorong-lorong gelap itu

(48) Negara kita akan tumbuh menjadi negara besar di dunia

(49) Ayah mulai berhenti merokok

Verba berjalan (47), tumbuh (48), dan berhenti (49) diikuti konstituen posverba berupa pelengkap. Pelengkap dalam klausa-klausa di atas adalah menyusuri lorong-lorong gelap itu, menjadi negara besar di dunia berkategori frasa verbal, dan merokok berkategori verba.

\section{3) Verba Berpelengkap Adjektiva}

Berikut ini contoh-contoh klausa berpelengkap adjektiva.

(50) Pak Raden dalam serial si Unyil berkumis tebal

(51) Bajunya berwarna kuning

(52) Guru-guru berpakaian putihputih

Verba berkumis (50), berwarna (51), dan berpakaian (52) diikuti konstituen posverba berupa pelengkap. Pelengkap dalam klausa-klausa di atas adalah tebal, kuning, dan putih-putih berkategori adjektiva.

\section{4) Verba Berpelengkap Adverbia (Frasa Adverbial)}

Berikut ini contoh-contoh klausa berpelengkap adverbial (frasa adverbial).

(53) Mereka diam sebentar

(54) UUDS tidak berlaku lagi

(55) Tabrakan maut itu terjadi Jumat malam

Verba diam (53), berlaku (54), dan terjadi (55) diikuti konstituen posverba berupa pelengkap. Pelengkap dalam klausa-klausa di atas seben tar, lagi, dan Jumat malam berkategori adverbia (frasa adverbial).

5) Verba Berpelengkap Numeralis (Frasa Numeral)

Berikut ini contoh-contoh klausa berpelengkap numeralia (frasa numeral).

(56) Laki-laki itu beristri tiga

(57) Kuda dan sapi berkaki empat

(58) Seekor ayam bertelur sebutir sehari

Verba beristri (56), berkaki (57), dan bertelur (58) diikuti konstituen posverba 
berupa pelengkap. Pelengkap dalam klausa-klausa di atas tiga, empat, dan sebutir sehari berkategori numeralia (frasa numeralia).

Verba pada klausa (43) sampai dengan (58) diikuti konstituen yang berupa pelengkap. Pelengkappelengkap tersebut dapat berkategori nomina (frasa nominal), verba (frasa verbal), adjektiva (frasa adjektival), adverbial (frasa adverbial), numeralia (frasa numeral). Kehadiran pelengkap dalam klausa-klausa di atas bersifat manasuka. Pelengkap yang bersifat manasuka mempunyai kemiripan dengan keterangan. Keterangan mempunyai salah satu ciri yang bersifat bukan inti klausa sehingga kehadirannya bersifat mana suka, ia bisa ada ataupun tidak ada. Namun, ciri lain keterangan yaitu mempunyai tempat bebas dan cakupan senantiasa lebih luas (meliputi seluruh klausa), tidak dimiliki oleh pelengkap yang bersifat mana suka. Pelengkap yang bersifat manasuka tidak dapat dipermutasikan di antara subjek dan predikat atau di depan subjek. Jadi, posisinya bersifat statis, hanya terletak setelah predikat.

- Mereka berdagang barang-barang antik

* Mereka barang-barang antik berdagang

* Barang-barang antik mereka berdagang

\section{Perilaku Semantis Verba}

Perilaku semantis verba berpelengkap dalam penelitian ini dideskripsikan berdasarkan makna inheren verba. Makna inheren verba meliputi verba pungtual, verba aktivitas, verba statis, dan verba statif.

\section{a. Verba Pungtual}

Berkut ini contoh-contoh klausa verba pungtual.

(59) Kakek batuk kering
(60) Dia mengangguk tanda setuju

Verba batuk (59) dan mengangguk (60) tergolong verba pungtual karena keberlangsungan situasinya dalam waktu sekilas. Verba tersebut tidak gramatikal bila bergabung dengan kata sedang, mulai, atau selesai. Verba pungtual mempunyai ciri-ciri nondinamis, nonduratif, telik, dan homogen.

\section{b. Verba Aktivitas}

Berikut ini contoh-contoh klausa verba aktivitas.

(61) Mia makan mangga mentah

(62) Mereka berjalan menyusuri lorong-lorong gelap itu

Verba makan (61) dan berjalan (62) tergolong verba aktivitas. Ciri-ciri verba perbuatan ialah selain dapat berdistribusi dengan kata selesai/usai. Dalam distribusinya dengan kata sedang, verba perbuatan bermakna progresif, menyatakan 'perbuatan sedang berlangsung'; dan dalam distribusinya dengan kata selesai/usai, verba perbuatan bermakna perfektif, yaitu menyatakan bahwa 'perbuatan itu telah selesai dilakukan'. Dengan demikian, kalimat (61) dan (62) tersebut dapat diperluas menjadi klausa berikut.

(a) Mia sedang makan mangga mentah

(b) Mia selesai makan mangga mentah

(a) Mereka sedang berjalan menyusuri lorong-lorong gelap itu

(b) Mereka selesai berjalan menyusuri lorong-lorong gelap itu

Ciri lainnya ialah verba perbuatan dapat dipakai untuk menjawab pertanyaan "Apa yang dilakukan oleh subjek?" Dengan demikian, dalam konteks klausa di atas, jawaban atas pertanyaan tersebut merupakan verba perbuatan.

(c) Apa yang dilakukan oleh Mia atau mereka? Jawabannya ialah makan atau berjalan. 
Disamping itu, verba perbuatan juga dapat dipakai untuk membentuk kalimat perintah. Misalnya "Makan!" atau "Berjalan!"

\section{c. Verba Statis}

Berikut ini contoh-contoh klausa verba statis.

(63) Perempuan itu duduk seorang diri di teras depan

(64) Para demonstran mogok makan

Verba duduk (63) dan mogok (64) tergolong verba statis. Verba statis mempunyai kemiripan dengan verba aktivitas. Ciri yang membedakan justru terletak pada kedinamisan dan ketelikannya. Verba duduk dan mogok bersifat nondinamis karena dalam aktivitasnya dapat tidak mengikutsertakan gerakan (mutasi).

\section{d. Verba Statif}

Berikut ini contoh-contoh klausa verba statif.

(65) Temanku sakit kepala

(66) Mereka tahu masalah itu

Verba sakit (65) dan tahu (66) tergolong verba statif. Verba statif bersifat homogen, keberlangsungannya bersifat tetap, tanpa disertai gerakan (non-dinamis) dan keberlangsungannya tidak memerlukan usaha atau tenaga, kecuali jika terjadi sesuatu yang menyebabkan atau terputusnya keadaan itu. Secara sintaktis, verba statif dapat berdistribusi dengan kata makin dan semakin.

(a) Temanku makin/semakin sakit kepala

(b) Mereka makin/semakin tahu masalah itu

\section{Simpulan}

Berdasarkan hasil penelitian yang sudah diuraikan di atas, verba berpelengkap dalam bahasa Indonesia dapat disimpulkan sebagai berikut.
1. Secara morfologis, verba berpelengkap dapat diisi oleh verba dasar bebas, verba turunan berafiks, dan verba bereduplikasi. Verba turunan berafiks dapat dibentuk oleh afiks $m e(N)$ - dengan bentuk dasar nomina, verba, adjektiva, dan numeralia; be $(R)$ - dengan bentuk dasar nomina dan verba; ter dengan bentuk dasar verba, me(N)-i dengan bentuk dasar adjektiva, me(N)- kan dengan bentuk dasar nomina, be(R)-kan dengan bentuk dasar nomina dan verba, beran dengan bentuk dasar verba, ke-an dengan bentuk dasar nomina, verba, adjektiva, adverbia, dan numeralia. Verba berduplikasi dapat dibentuk melalui afiksasi dengan pola prefiks + (dasar+dasar) dan melalui perubahan bunyi dengan pola (prefiks+dasar) + dasar.

2. Berdasarkan perilaku sintaktis, verba berpelengkap dapat diisi oleh pelengkap berkategori nomina (frasa nominal), verba (frasa verbal), adjektiva (frasa adjektival), adverbia (frasa adverbial), numeralia (frasa numeral). Kehadiran pelengkap dapat bersifat wajib dan manasuka. Relasi antara verba dengan konstituen praverba (dalam hal ini subjek) termasuk verba antipasif dan verba antiaktif.

3. Berdasarkan perilaku semantis, makna inheren verba berpelengkap dapat diklasifikasikan menjadi verba pungtual, verba aktivitas, verba statis, dan verba statif.

\section{Daftar Pustaka}

Alwi, Hasan, (et. al.). 2000. Tata Bahasa Baku bahasa Indonesia. Jakarta: Balai Pustaka.

Coolsma, S. 1984/1985. Tata Bahasa Sunda. (Terjemahan Husein Widjajakusumah dan Yus Rusyana). Jakarta: Djambatan. 
Djajasudarmana, T. Fatimah. 1993. Metodologi Linguistik. Bandung: Eresco.

Kridalaksana, Harimurti. 1990. Kelas Kata dalam Bahasa Indonesia. Jakarta: Gramedia.

Kridalaksana, Harimurti. 1993. Pembentukan Kata dalam Bahasa Indonesia. Jakarta: Gramedia.

Moeliono, Anton M. (et. al.). 1997. Tata Bahasa Baku Bahasa Indonesia. Jakarta: Gramedia.

Ramlan, M. 1987. Ilmu Bahasa Sintaksis. Yogyakarta: CV Karyono.
Sugono, Dendi dan Titik Indiyastini. 1993. Verba dan Komplementasinya. Jakarta: Pusat Bahasa.

Tadjuddin, Moh. 1993. "Makna Aspektualitas Inheren Verba Bahasa Indonesia", dalam Majalah Ilmiah Universitas Padjajaran No. I, Vol. II.

Verhaar, J. W. M. 1997. Pengantar Linguistik. Yogyakarta: Gadjah Mada University Press. 